\title{
DAKWAH BI AL-KITABAH \\ ( Analisis Komunikasi Persuasif Dalam Novel Islam Anak Rantau)
}

\author{
Fathur Rohman \\ Universitas Muhammadiyah Metro lampung \\ Fathurohmanadja619@gmail.com
}

\begin{abstract}
Abstrack
Currently preaching activities are not only through the pulpit of the mosque, recitation, and lectures only. The method of writing Da'wah Bil Kitabah is through writing. Posts that support all who read this paper with the aim of dragging to Allah SWT, then this paper is da'wah. Persuasive communication can not only be done verbally, but can also be applied in a writing and can be made as a propaganda media. A paper consisting of a novel by Ahmad Fuadi, is a paper that contains messages using persuasive communication techniques with a very crisp language style that is easily understood to make propaganda messages that are easily carried by the community which are then poured into written novels called "Overseas Children ". This study uses a qualitative research method by using content analysis (content analysis) so that the results of this research are the da'wah done by Ahmad Fuadi through his novel entitled Islamic Children Overseas Novels related to five persuasive communication techniques namely: association techniques, fear techniques arise, pay of idea techniques, icing device techniques, cognitive disonance techniques
\end{abstract}

Kata Kunci: Da'wah, Persuasive Communication, Novels 


\section{A. Pendahuluan}

Sebutan mengajak atau berdakwah menurut Muhtadi serupa dengan pidato,dan pengajian. Seorang Kolumnis, wartawan, atau pembuat karya tulis lainnya tidak disebutkan sebagai kegiatan dakwah. Secara umum penyampaian merupakan sebuah jalan seseorang dalam mempengaruhi orang lain agar bisa melaksanakan perubahan, baik sikap dan perilakunya. Seluruh wujud aktivitas mencatat bisa disebut menjadi soerang jurnalis. Melalui kreasi catatannya, seorang jurnalis akan berupaya mempengaruhi para pembacanya sampai bisa pada lingkup yang amat luas. ${ }^{1}$

Salah satu wujud kreasi berupa catatan adalah berupa Novel. Novel melambangkan kreasi pustaka fiksi yang dikerjakan bagi seorang pengarang menggunakan beragam konsep,fiktif, dan tercantum nasihat tertentu, maka menjadi sebuah alur cerita yang tersusun secara rapih, singkat dan gampang dimengerti oleh pembaca. Fiksi merupakan fiksi menceritakan beragam persoalan sosial manusia berisi hubungan pada sesama, hubungan dengan diri sendiri, beserta hubungan dengan Tuhan. Fiksi merupakan lukisan hasil dialog, pemikiran, dan anggapan kreator terhadap alam dan aktivitas.

Meski berbentuk hasil kegiatan fantasi, fiksi, tetapi bukan berarti kalau fiksi dianggap seperti hasil kerja angan-angan saja, melainkan pendalaman dan perenungan secara meluas, perenungan terhadap asas jiwa dan kehidupan, perenungan akan dilakukan lewat penuh kesadaran dan kewajiban. Fiksi membentuk kreasi ilusif yang dilandasi kesadaran dan kewajiban dari aspekinspirasi bagai kreasi seni. ${ }^{2}$

Sebuah karangan fiksi ditulis oleh seorang pengarang antara lain demi membuktikan model kehidupan yang diinginkannya. Fiksi mengandung penerapan moral dalam sikap dan tingkah laku para tokoh sesuai pandangannya tentang moral. Melewati prosa, perilaku dan perbuatan tokohnya, diharapkan pembaca bisa memetik pesan dan kearifan yang disampaikan. Pesan moral yang disampaikan berisi prosa fantasi berbeda akibatnya dibanding melewati artikel nonfiksi, sehingga kreator ada ambisi memberikan amanat terkandung atas dijadikan sebuah prosa. ${ }^{3}$ Agama Islam senantiasa mengajarkan kebaikan, baik itu

1 Muhtadi, Asep Saeful. Komunikasi Dakwah (Bandung: Simbiosa Rekatama Media, 2012), h. 93.

2 Nurgiyantoro, Burhan. Teori Pengkajian Fiksi(Yogyakarta :Gadjah Mada University Press, 2013), h.3.

${ }^{3}$ Ibid., h. 431. 
melewati ujaran ataupun karya. Pada prinsipnya Islam membimbing umatnya untuk tidak melaksanakan aktivitas yang tercela, kasar apalagi memaksa.

Hubungan persuasi melambangkan hubungan akan meyakinkan gaya berasumsi, perilaku, dan perbuatan orang beserta memerlukan rancangan yang tenang dan menyemangati. Efektivitas persuasi tergantung pada kesuksesan metode hubungan. ${ }^{4}$ Metode hubungan yang efesien memerlukan satuan data antara pengirim dan penerima catatan perihal mengenai isi pesan. Persuasi ialah salah satu cara buat merubah perilaku dan sikap seseorang ataupun himpunan beserta penyampaian laporan tertentu. sikap dan perilaku sama-sama bercantuman, sehingga akan mengubah sikap perlu mengamati dan menguasai perilaku. Perilaku yang bermanfaatakan menimbulkan sikap yang searah dengan amanat yang disampaikan. ${ }^{5}$ Kebalikan dari hubungan persuasi ialah hubungan koersif. ${ }^{6}$ Hubungan persuasi dan hubungan koersif persis dalam tujuannya yaitu akan mempengaruhi atau merubah perilaku dan kelakuan. Bedanya hubungan koersif memakai gaya dengan kekerasan dan ancaman.

Hubungan koersif menurut Schein dan Lifton menjelaskan bahwa untuk mempersuasi seseorang atau himpunan supaya perilaku dan kelakuan berubah, maka komunikator mengirim pesan dengan gaya menekan, memaksa, menyampaikan perintah atau bahkan dengan rencana biarpun mencuci otak. Sikap koersif ini, seseorang yang memiliki kekuatan akan kian bebasnya mengendalikan orang yang berada dibawah kedaulatannya. ${ }^{7}$ Hubungan koersif bisa digambarkan dengan perilaku agresif dan provokasi, karena mempengaruhi seseorang dengan langkah yang buruk. Langkah tersebut menggambarkan cerita yang benar-benar terjadi dalam kehidupan, maka selain bisa mempersuasi dalam kenyataan juga bisa dimasukan dalam sebuah artikel.

Artikel menggambarkan dampak media massa cetak yang mempunyai umur jangka panjang karena artikel berwatak terdokumentasi. Selain sampel tersebut, dalam media massa berbentuk

69.

${ }^{4}$ Hanurawan, Fattah. Psikologi Sosial (Bandung: PT Remaja Rosdakarya, 2015), h.

5 Ma'arif, Bambang Saiful. Psikologi Komunikasi Dakwah (Bandung: Simbiosa Rekatama Media, 2015), h. 161.

${ }^{6}$ Jumantoro, Totok. Psikologi Dakwah(Penerbit Amzah, 2001), h. 148.

${ }^{7}$ Liliweri, Alo. Komunikasi Serba Ada Serba Makna (Jakarta: Kencana, 2011), h. 300. 
artikel di internet misalnya Instagram, facebook, twitter ataupun artikel di internet lainnya, dewasa ini banyak yang berisi hubungan koersif diantaranya : agresif dan provokasi. Persoalan timbul kala melihat kenyataan yang terjadi, bahwa aksi dan ajakan hubungan koersif bisa memunculkan efek yang tidak baik. Akibat yang tidak baik menimbulkan perubahan pandangan, perilaku dan sikap yang buruk dengan rasa takut, tertekan atau justru memicu rasa tidak senang. Masyarakat selalu memperoleh data melalui media massa hendaknya lebih ketat dalam menyerap dan memilih sebuah data yang muncul, hendaknya tidak gampang terpengaruh atas semua data yang berikan baik melalui media audio maupun media cetak.

Dalam kitab suci Al-Quran sudah dipaparkan, bahwa tidak diperbolehkan menerima laporan secara mentah dan harus cermat terlebih dahulu perihal asal mula suatu bukti laporan tersebut. Penyampaian amanat Islam dengan memakai hubungan persuasi masa kini sudah mulai beragam. Ustad tidak cuma berpacu pada dakwah yang dilaksanakan di gedung, rumah ataupun masjid melainkan melalui tulisan hingga media massa online dan audio visual. Sama halnya seperti Ahmad Fuadi, yangmenguraikan hubungan persuasinya lewat novel atau buku yang diterbitkannya. Tidak jauh berselisih dengan Tere Liye, Habiburrahman El-Shirazi, dan Asma Nadia yang menata pesan persuasinya lewat pernyataan asmara ataupun rindu yang bisa menggiringi remaja atau dewasa akan menangkap isi-isi dari artikel yang diterbitkan.

Bukan hanya berakhir dengan media artikel, Hanan Attaki berceramah dengan gaya persuasi yakni mengajak anak muda untuk nongkrong bersama-sama dalam suatu ruang yang umum,demi harapan dan sasaran berdialog ke arah ajakan yang berkarakter lebih mudah, tenang supaya mampu diterima oleh seluruh kalangan dan mad'u tak merasa tertekan, senang bahkan tidak jenuh. Hubungan persuasi sebagai satu hal yang amat penting bagi seorang ustad. Mengingat mad'u yang amat beragam baik dari segi perilaku, sikap, atau cara pikir. Menuju mad'u agar menjalankan seruan ustad, butuh mempersiapkan bahan atau pesan yang konstruksinya bisa melakukan kesadaran, afeksi, dan psikomotorik pendengar terguncang. Pembaca, mad'u, atau penontonnya bisa terpengaruh secara menyeluruh.

Bahan ajakan bisa ditunjang dengan kreasi kesaasastraan, salah satunya ialah kreasi sastra novel. Kisah fiksi dalam kreasi sastra novel bisa digunakan sebagai bahan ajakan. Bahan ajakan yang berbentuk 
kaidah Islam atau seluruh objek yang layak disampaikan materi kepada objek ajakan, yaitu menyeluruh kaidah Islam yang ada di Kitab suci AlQur'an dan Sunah Rasulullah. Menurut Ali Aziz kreasi sastra yang digunakan pesan atau bahan ajakan harus berdasarkan etika yaitu isinya berisi hikmah yang mengajak kepada Islam atau membawa berbuat kebaikan. ${ }^{8}$ Bahan ajakan menurut Saerozi ialah pesan yang diberikan oleh ustad kepada pendengar yang berisi hakikat dan kearifan bagi manusia yang bersumber Al-Quran dan hadis, ${ }^{9}$ sedangkan yang dimaksud hakikat dalam kisah fiksi ialah pemikiran nilai-nilai hakikat seruan Islam yang tergolong dalam Al-Quran dan hadis yang disampaikan melewati sebuah kreasi sastra salah satunya novel.

Keabsahan dalam dunia fiksi ialah hakikat yang searah dengan akidah pencerita, keabsahan yang telah diketahaui kebenarannya sesuai dengan pemikiran terhadap masalah hidup dan kehidupan Keabsahan dalam kreasi fiksi tidak mesti sejalan dengan keabsahan yang berlaku di dunia nyata, contohnya keabsahan dari segi hukum, moral, agama, logika dan sebagainya. Sesuatu yang mungkin tidak terjadi dan tidak dianggap krusial di dunia, mungkin saja terjadi dan dianggap ada di dunia fiksi. Keabsahan sebuah kisah fiksi yang baik ialah kemungkinan, probabilitas, atau sepemikiran. Serasi dengan nama dan karakternya.

Kisah fiksi ialah kreasiartistik, inovatif yang tidak mengharuskan adanya pembenaran dengan bukti untuk mempunyai keabsahan yang sesuai logika. ${ }^{10}$ Adapun sejumlah kreator yang menggunakan resistensia akibat pesan menjadi alat untuk memberikan hubungan persuasi yaitu Tere Liye, Ahmad Fuadi, Asma Nadia, dan Habiburrahman El Shirazy. kreator yang telah disebutkan, menguraikan kreasi novelnya ditata dengan kalimat dan kata-kata yang disusun dengan rapi. Maksudnya suapaya mad'u bisa dengan gampang mengerti bagaimana isi dan tujuan pesan yang ingin diberikan oleh kreator. Mereka menata penyampaiannya dengan teratur supaya bisa digunakan oleh berbagai macam kalangan masyarakat. Nama-nama kreator yang sebut diatas, diambil salah seorang kreator yakni Ahmad Fuadi.

Kisah fiksi Ahmad Fuadi dinilai mampu menyampaikan dorongan dan semangat dalam menjalani aktivitas sehari-hari. Kreasi

${ }^{8}$ Aziz, Ali. Ilmu Dakwah Edisi Revisi (Jakarta: Prenanda media Group, 2016), h. 329.

${ }^{9}$ Saerozi. Ilmu Dakwah. 2013 (Yogyakarta: Ombak, 2013), h. 37.

${ }^{10}$ Nurgiyantoro, Burhan. Teori Pengkajian Fiksi (Yogyakarta : Gadjah Mada University Press, 2013), h.7. 
Ahmad Fuadi condong objektif, mampu dibaca berbagai kalangan. Dengan bahasa yang gampang dimengerti banyak kandungan nilai-nilai Islami yang dimasukkan kedalam tulis-tulisannya, sehingga peneliti mengangkat novel kreasi Ahmad Fuadi yang berjudul "Anak Rantau" untuk materi observasi, kemudian menjelaskan cara hubungan persuasi yang dipakai oleh Ahmad Fuadi. Penelitiingin memperlihatkan kepada pembaca bahwa kaidah-kaidah Islami tak hanya di lihat secercah melewati sebuah tajuk melainkan melewati arti yang tercantum didalamnya. Novel Anak Rantau karya Ahmad Fuadi isinya menggambarkan pertualangan seorang anak yang ditinggalkan ayahnya dikampung halaman yang bernama Hepi. Kemudian, Hepi bekerja keras berusaha membeli tiket pesawat untuk pulang kerumah ayahnya di Jakarta.

Berbagai macam cara yang dikerjakan untuk menghasilkan uang. Bermula dari menolong Mak Tuo Ros di Lapaunya, sebagai asisten Bang Lenon, sampai Hepi mencoba mendatangi Pandeka Luko guna meminta pertolongan sesuai yang dibicarakan teman akrab Hepi yakni Atta dan Zen bahwa Pandeka Luko pempunyai alat pencetak uang. Selain itu, Hepi ialah salah satu aktor terbaik yang menjalankan perintah Al-Quran surat Al-Hujurat ayat 6 tersebut. Hepi tidak cepat mengakui terhadap apa yang dibicarakan umumnya masyarakat perihal Pandeka Luko. Atas kegagahan, Hepi memperlihatkan sendiri informasi tersebut dengan gagah menemui dan mendatangi sampai memasuki rumah Pandeka Luko yang banyak dibicarakan masyarakat bahwa rumah itu angker. Perjalanan tidak sampai pada penghampiran terhadap Pandeka Luko. Ada sesuatu yang baru terasa tumbuh dalam hati Hepi,yakni mau mengungkap persekongsian guna melindungi desanya dari kejahatan. Bermula dari persekongsian ini perjalanan Hepi di mulai, sampai Hepi hampir kehilangan nyawa dan kedua teman Hepi yakni Atta dan Zen.

Berlandaskan penjelasan diatas, penulis teratrik untuk mengkaji hubungan komunikasi persuasif didalam novel Islami Anak Rantau, sampai sanggup dijadikan rencana dalam memberikan nilai-nilai Islam melewati media kreasi dengan tujuan mampu menjadi suri tauladan untuk masa kedepannya dalam meningkatkan seruan melewati kreasi tulisan khususnya novel.

\section{B. Metode Penelitian}

Aktitas penelitian ini menggunakan metode penelitian kualitaif, yang mana penelitian kualitaif merupakan kegiatan penelitian yang 
sumber datanya adalah berupa kata-kata untuk kemudian di analisis. ${ }^{11}$ Penelitian yang bertemakan Analisis Komunikasi Persuasi Dalam Novel Islami Anak Rantau, mencoba untuk menemukan pemahaman baru berkaitan dengan dakwah, sehingga untuk mendapatakn hal baru tersebut dipandang perlu melakukan penelitian dengan menggunakan metode penelitian yang relevan. Jadi metode penelitian kualitatif dengan pendekatan analisis isi (Conten analysis). Dalam penelitian ini lebih dikehendaki karena menurut Krippendorff Analisis isi adalah suatu teknik penelitian untuk membuat inferensi-inferensi yang dapat ditiru (repicable) dan shahih data dengan memperhatikan konteksnya. ${ }^{12}$

\section{Pembahasan}

\section{Definisi Persuasi}

Kata persuasi berawal dari bahasa Inggris persuasion yang berinduk terhadapkata kerja to persuade, yang artinya mempengaruhi, mengajak, memperingatkan. Aktivitas mempengaruhi, mengajak, memperingatkan atau sejenisnya ialah membangkitkan seorang untuk menjalankan sesuatu dengan langsung, dengan senang hati, atas kemauan sendiri tanpa adanya paksaan. ${ }^{13}$

Secara etimologi sebutan persuasi berawal dari bahasa Latin persuadeo, yang terdiri dari kata per maknanyabersifat ampuh atau effectively dan kata suadeo maknanya membujuk, merayu, terpercaya. Dengan begitu sebutan persuadeo secara harfiah artinya membujuk, merayu, meyakinkan secara efesien. Dalam bahasa Inggris kalimat tersebut diambil dan seterusnya diubah menjadi persuasion atau to persuade.

Kata persuasion bermakna the art or power to persuade.Persuasi merupakan mempengaruhi, ajakan, atau memastikan bagian lain supaya mau menjalankan sesuatu yang penyampai pesan inginkan dengan kesadaran diri sendiri tanpa merasa penyampai pesan yang

\footnotetext{
${ }^{11}$ Anton Widodo, Fathurohman, Dakwah Islam Di Era Revolusi Industri 4.0,
} Khabar: Jurnal Kounikasi Penyairan Islam, Vol.1 No.1 Juli-Desember 2019 hal 51

${ }^{12}$ Krippendorff, Klaus. Analisis Isi Pengantar Teori dan Metodologi. 1991.Jakarta: Rajawali Pers h 15

13 Sastropoetro, Santoso.Partisipasi, komunikasi, Persuasi dan Disiplin Dalam Pembangunan Nasional (Bandung: Penerbit Alumni, 1998), h. 246. 
menyuruhnya. ${ }^{14}$ Persuasi bertumpu dari penyebab kebahagian yang terdapat pada diri seseorang terhadap suatu sasarannya, baik manusia, karier, alat ataupun dalam kondisi tertentu. Seseorang yang girang terhadap sesuatu sasaran akan tingkah sesuai dengan apa yang diinginkannya. ${ }^{15}$

Persuasi ialah aktivitas mental dalam upaya memperdayai perilaku, perbuatan, anggapan, dan tingkah laku individu atau khalayak ramai. memperdayai perilaku, perbuatan, anggapan, dan tingkah laku bisa dilaksanakan dengan berbagai macam cara. Teror, boikot, pemerasan, penyuapan dan sebagainya bisa juga meminta orang lain bertingkah atau bersipat seperti yang diinginkan. ${ }^{16}$

2. Dakwah

a. Definisi Dakwah

Secara istilah atau bahasa, kalimat dakwah bersumber dari bahasa Arab yakni $d a^{\prime} a-y a d^{\prime} u-d a^{\prime} w a t a n$ yang maknanya mengajak, menyeru, mengundang. ${ }^{17}$ Sementara orang yang mengerjakan seruan atau ajakan dijuluki sebagai seorang ustad. anjuran ajakan atau seruan mengambarkan cara implementasi (mengerjakan), maka yang melakukan dikenal dengan sebutan muballigh yang mananya penyampai atau penyeru. Definisi mengajak secara istilah menurut Syaikh Ali Mahfudz ialah mendukung mahluk hidup untuk melakukan kebaikan, mematuhi arahan, menyerukan kebajikan dan menjauhi larangannya supaya seorang mendapatkan hikmah baik di dunia maupun di akhirat. Sementara menurut M. Natsir mengajak ialah upay-upaya menganjurkan dan memberikan kepada setiap manusia dan semua kaum muslim/ahfertilisasi Islam perihal ajaran dan sasaran mahkluk hidup di dunia ini, dan yang mencakup al-amar bi alma"ruf an-nahyu an al-munkar dengan berbagai jenis proses dan

${ }^{14}$ Hutagalung, Inge. Teori-Teori Komunikasi Dalam Pengaruh Psikologi (Jakarta Barat: Indeks, 2015), h. 74.

${ }^{15}$ Ma'arif, Bambang Saiful. Psikologi Komunikasi Dakwah (Bandung: Simbiosa Rekatama Media, 2015), h.79.

${ }^{16}$ Slamef: fifektifitas Komunikasi dalam Dakwah PersuasifJURNAL DAKWAH, Vol. X No. 2, Juli-D.sernber 2009

${ }^{17}$ Harles Anwar \& Mualimin Dakwah Melalui Pembinaan Keagamaan Terhadap Masyarakat Muslim Pedalaman Oleh Penyuluh Agama Islam Non Pns Kecamatan Tebas, Sambas, Jurnal Bimbingan penyluhan Islam Vol.1 No.1 januari-Juni 2019 hal 24 
media yang diperkenankan akhlak dan memandu pengetahuannya dalam perikehidupan dan bermasyarakat bernegara. ${ }^{18}$

1) $D a " i$ (Pelaku Dakwah)

Kata da"i secara umum selalu dijuluki sebagai mubaligh (orang yang menyampaikan ajaran Islam) akan tetapi julukan ini implikasinya sangat kecil karena khalayak pada umumnya lebih condong memaknai mubaligh sebagai orang yang memberikan pemahaman Islam melewati perkataan, seperti pembicara agama, khatib (orang yang berkhutbah), dan sebagainya. ${ }^{19} D a{ }^{*} i$ ialah seorang yang melakukan seruan, baik lewat kata-kata, catatan, ataupun kegiatan, yang dilaksanakan secara seorang, khalayak, ataupun himpunan atau majelis. ${ }^{20}$

2) Mad'u (Penerima Dakwah)

Mad'u adalah mahkluk yang menjadi target seruan atau mahkluk menerima seruan, baik selaku perorang maupun khalayak, baik mahkluk yang berkeyakinan Islam ataupun tidak, atau dengan bahasa lain mahluk secara menyeluruh. ${ }^{21}$

$D a " i$ dalam pemberian seruannya harus mengetahui psikologis mad'u. Hal tersebut meringankan pendengar supaya bisa dengan gampang memahami kaidah-kaidah seruan yang diberikan.

3) Maddah Dakwah (Materi Dakwah)

Bahan atau kaidah ajakan ialah kaidah yang berisi hukum Islam atau semua yang harus diberikan subjek kepada objek dakwah, adalah menyeluruh hukum Islam yang terkandung didalam AlQuran dan sunah Rasulullah. ${ }^{22}$ Kaidah dan bahan seruan harus diberikan secara baik dan mudah, supaya mad'u bisa memahami dan dapat menambah ilmu pengetahuan dan pengalaman kepada mad'u dengan mudah. Pada awalnya bahan seruan Islam bergantung pada sasaran dakwah yang hendak dicapai. tetapi, secara umum bahan ajakan bisa dijelaskan menjadi tiga bagian yaitu:

(a) Masalah keimanan (aqidah).

\footnotetext{
${ }^{18}$ Amin, samsul Munir. Ilmu Dakwah (Jakarta: Amzah, 2013), h. 1-3.

${ }^{19}$ Saerozi. Ilmu Dakwah (Yogyakarta: Ombak, 2013), h. 35.

${ }^{20}$ Sukayat, Tata. Ilmu Dakwah (Bandung: Simbiosa Rekatama Media, 2015), h. 24.

${ }^{21}$ Saerozi. Ilmu Dakwah (Yogyakarta: Ombak, 2013), h. 36.

${ }^{22}$ Sukayat, Tata. Ilmu Dakwah (Bandung: Simbiosa Rekatama Media, 2015), h. 25-
}

26. 
Aqidah adalah dasar keyakinan dalam agama Islam.

(b) Masalah keislaman (syariat).

Syariat ialahsemua ajaran dan aturan-aturan yang terkandung di dalam Islam, baik yang berkaitan mahlukdengan Allahswt, ataupun antar mahkluk sendiri.

(c) Masalah budi pekerti (akhlaqul karimah).

Hukum akidah atau budi pekerti dalam Islam tercantum kedalam bahan ajakan yang penting untuk diberikan kepada khalayak dan mad'u.

Islam menjunjung tinggi hukum-hukum kebajikan dalam kegiatan manusia. Dengan akidah yang baik dan kepercayaan agama yang kuat maka Islam mencegah terjadinya depresi moral. Menurut Barmawi Umari bahan ajakan Islam antara lain: ${ }^{23}$ Pertama,Aqidah, menyampaikan dan menumbuhkan pemahaman aqidah Islamiyyah berdasarkan dari rukun iman yang prinsipil dan segala perinciannya. Kedua, Akhlak, menjelaskan terkait akhlak mahmudah dan akhlak madzmumah dengan segala dasar, hasil dan akibatnya, diikuti oleh contoh-contoh yang telah pernah terjadi dalam sejarah. Ketiga Ahkam, menerangkan jenis hukum mencakup soal-soal ibadah, al-ahwal as-syahsiyah, muamalat yang wajib dilakukan oleh setiap umat muslim. Keempat Ukhuwah, menjalin silaturahmi kesesama umat muslim yang diwajibkan oleh Islam.

3. Hubungan Komunikasi Persuasif Dengan Dakwah

Cara menyeru, mengajak adalah jenis hubungan itu sendiri, akan tetapi bukan hanya satu-satunya hubungan. Seruan ialah hubungan khusus, yang membedakan dengan hubungan secara terbuka ialah proses dan sasaran yang akan diraih. Sasaran dari hubungan menginginkan perlunya kontribusi dari hubungan atas konsep-konsep atau kaidah yang diberikan supaya dengan kaidahkaidah tersebut bisa merubah perilaku dan perbuatan yang diinginkan pendakwah tersebut.

Seorang ustadz sebagai penyampai pesan yang diinginkan kontribusinya, dan akan datang impian supaya penerima mampu berperilaku dan melakukan sesuai isi kaidah yang diberikan. Bentuk khusus yang memisahkan ialah terjadi pada rancangan yang

${ }^{23}$ Amin, samsul Munir. Ilmu Dakwah (Jakarta: Amzah, 2013), h. 92. 
diberikan secara persuasi, dan targetnya adalah menginginkan terbentuknya transisi atau pembentukan pendirian perilaku dan perbuatan sejalan dengan hukum-hukum agama Islam. ${ }^{24}$ Hubungan menggambarkan tahapan dari suatu aktivitas memperdayai yang mampu memakai langkah persuasi. Tujuan hubungan persuasi dalam struktur seruan ialah komunikasi yang selalu bertujuan pada aspek-aspek moral pendengar dalam upaya menghidupkan kepekaan mad'u untuk memahami dan melakukan hukum agama Islam. Cara hubungan persuasi untuk meraih sasaran dan targetnya, maka seorang penceramah harus mempersiapkan sebuah strategi secara matang. Sedangkan, sebuah strategi dikerjakan berlandaskan elemen-elemen cara hubungan ${ }^{25}$. Bagi seorang ustad atau penceramah, satu materi seruan yang akan disampaikan harus sudah jelas materinya, namun yang harus menjadikan gagasannya ialah manajemen kaidah. kaidah perlu disusun sesuai dengan para pendengar atau mad'u seperti yang akan dijadikan tujuan. ${ }^{26}$

4. Novel

a. Definisi Novel

Novel (Inggris: novel) melukiskan bentuk kreasi tulisan yang disebut fiksi. Sampai, dalam kemajuannya yang seterusnya novel diakui bersamaan dengan fiksi. Julukan novel dalam bahasa Inggris dan inilah yang seterusnya masuk ke Indonesia berawal dari bahasa Italia novella (yang dalam bahasa Jerman: novella). Menurut istilah novella bermakna satu benda baru yang halus, dan setelah di maknai sebagai cerita pendek dalam bentuk tulisan. sebutan novella dan novelle menyimpan arti yang mirip dengan sebutan Indonesia novelet (Inggris novelette), yang bermakna suatu kreasi tulisan fiksi yang banyaknya cukupan, tidak terlalu banyak tetapi juga tidak terlalu sedikit.

\section{1) Panjang Cerita}

${ }^{24}$ Anas, Ahmad. Paradigma Dakwah Kontemporer (Semarang: PT Pustaka Rizki Putra, 2006), h. 73.

${ }^{25}$ Mubasyaroh, Strategi Dakwah Persuasif dalam Mengubah Perilaku Masyarakat, Ilmu Dakwah: Academic Journal for Homiletic Studies Volume 11 Nomor 2 (2017) 311 324DOI: 10.15575/idajhs.v12i.2398http://journal.uinsgd.ac.id/index.php/idajhs ISSN 16930843 (Print) ISSN 2548-8708 (Online) hal 313-315

${ }^{26}$ Ilaihi, Wahyu. Komunikasi Dakwah (Bandung: PT Remaja Rosdakarya, 2010), h. 125. 
Novel mengambarkan suatu kisah yang sedikit dan tidak sedikit halamannya, maka novel bisa mempresentasikan suatu hal dengan lugas, menyediakan sesuatu yang tidak sedikit, lebih rinci, lebih detil, dan lebih sering mengaitkan bermacam jenis persoalan yang berbelit-belit. Kejadian itu melingkup beragam bagian kisah yang membuat novel itu.

2) Keunggulan Novel

Keunggulan novel yang khusus ialah keahliannya memberikan persoalan yang bertele-tele dengan lugas, mengkreasikan suatu panggung yang jadi. perihal itu membentuk novel untuk menguraikannya menjadi lebih gampang sekalian lebih ruwet. Lebih gampang karena tak meminta mengerti problem yang bertele-tele dalam jenis (dan waktu) tidak banyak. Kebalikannya lebih ruwet karena berbetuk penyusunan dalam peristiwa yang luas yang bermakna unit komunitas atau tumbuh yang lebih.

3) Bagian Pembuatan Novel

Bagian Peratma pembuatan novel adalah merencanakan. Novel mempunyai ketidak keterkaitan pada banyaknya kisah yang mendukung keleluasaan setiap kreator, biasanya mempunyai banyak rencana. Berdiri banyak rencana terbaik atau suatu rencana terbaik dan bagian-bagian rencana. Rencana awal membuat masalah awal yang bagian vital permasalahan yang dikisahkan, sekalipun bagian-bagian perencanaan ialah berbentuk (timbulnya) masalah-masalah susulan yang mampu menahan, memperjelas, menjadi penyebab, dan menguntungkan masalah pokok untuk sampai ke titik puncak. ${ }^{27}$

Bagian kedua adalah judul novel bisa mempersembahkan lebih banyak judul tema, yakni lebih dari satu judul pokok dan beberapa judul susulan. perihal itu seiring dengan adanya perncanaan pokok dan bagian-bagian perencanaan yang membawakan suatu masalah pokok dan faktor-faktor penyuport (susulan). Kondisi tersebut seiring dengan keahlian novel yang mampu menyatakan beragam

${ }^{27}$ Ahmad Zaini Dakwah Melalui Media CetakAT-TABSYIR, Jurnal Komunikasi Penyiaran Islam Volume 2, Nomor 2, Juli - Desember 2014 68-69 
problem kegiatan yang seluruhnya akan diberikan kreatornya lewat kreasi model novel ini.

\section{b. Komponen-Komponen Novel}

Novel mengambarkan suatu keseluruhan, suatu totalitas yang berkarakter bagus. Sebagai suatu keseluruhan, novel memiliki bab-bab, elemen-elemen yangsaling bersangkutan satu dengan yang lain secara kuat dan saling mengaitkan. Jika novel disebut sebagai suatu kebulatan itu, salah satu elemen penggerak kisah itu, salah satu bagian proses mahkluk hidup itu.

1) Komponen Esensial Novel

Komponen esensial (intrinsik) elemen-elemen yang menumbuhkan kreasi bahasa itu sendiri. Elemen-elemen yang menimbulkan sebuah naskah datang sebagai naskah bahasa, unsur-unsur yang secara konkrit akan ditemui jika orang melihat kreasi bahasa. Komponen esensial suatu novel ialah elemen-elemn yang secara spontan ikut andil membuat kisah. kesinkronan antar bermacam komponen esensial yang membentuk suatu novel berbentuk. Atau kebalikannya, jika diterawang dari sisi pengamat elemen-elemen ini yang akan ditemui dalam mengamati sebuah novel. Elemen yang dituju untuk mengecap separuh contohnya, fenomena, kisah, perencanaan, judul, membentuk karakter, konteks, cara melihat kisahnya, satra atau cara bahasa, dan sebagainya.

2) Komponen Pembentuk Novel

Komponen pembentuk (ekstrinsik) ialah elemen-elemen yang bertempat di luar naskah bahasa, namun secara tidak spontan mempengaruhi bentuk atau proses kehidupan naskah bahasa. Secara lebih khas bisa disebutkan sebagai elemenelemen yang mempengaruhi tumbuh kisah sebuah kreasi bahasa, tetapi individu tidak masuk sebagai bab di dalamnya. Sebagaimana perihalnya komponen esensial, komponen pembuat juga terbagi dari sebagian elemen-elemen. Elemenelemen yang ditujukan antara lain yaitu kondisi filosofi sendiri penulis yang mempunyai perilaku, kepercayaan, dan pandangan hidup yang semuanya itu bisa mempengaruhi kreasi yang dibuatnya. Singkat kata komponen profil penulis akan ikut memutuskan desain kreasi yang diperolehnya. Komponen pembentuk seterusnya ialah mental, baik yang 
berbentuk moral kreator (yang meliputi cara artistiknya), moral pembaca, ataupun implementasi asas mental dalam kreasi. Kondisi di area kreator seperti perniagaan, kebijakan, dan masyarakat juga bisa berperan terhadap kreasi bahasa. Komponen pembuatan lain contohnya ideologi hidup suatu warga, bermacam kreasi seni yang lain, dan antara lain. ${ }^{28}$

\section{Novel Islami}

Islam menganjurkan kepada umat muslim untuk sering melakukan kebajikan, baik secara tutur kata maupun artikel. Sebagian kecil bisa diberikan lewat kreasi artikel berupa novel. Pada sumbernya Islam dan Islami tidak sama. Mahkluk bisadisebut Islam karena berlandaskan keluarga turun temurun. Akan tetapi belum pasti mahluk tersebut bisa sebagai Islami. mahkluk disebut Islami jika telah melakukan anjuran dan hukum yang telah dijelaskan dalam Al-Quran dan hadis dan tidak melakukan perbuatan yang dilarang. Tetapi juga kebalikannya mahkluk tidak memeluk agama Islam tetapi mempunyai roh dan sifat Islami yang sejalan apa yang tercantum dalam Al-Quran. Aspek-aspek yang menjadi persoalan tersebut, bukan hanya sekedar melihat lewat kenyataan aktivitas, tetapi bisa dimasukkan dan diberikan dalam suatu kreasi bahasa artikel yang sejenis novel..$^{29}$

Melalui kreasi artikelnya, penulis memakai bermacam gaya dan strategi dalam memberikan kaidah yang mau diberikan kepada pembaca. maksudnya supaya pembaca berjalannya waktu bisa melaksanakan transisi dengan tanpa pembaca sadari baik dalam ingatan, perilaku ataupun sifat sesudah membaca kaidah-kaidah yang berikanisi novel. Novel menyampaikan fungsi sebagai usaha pelipur lara, bahkan juga berupaya memberikan norma-norma hukum Islam supaya novel tersebut bisa disebut sebagai novel Islami. Hukum agama Islam itu berlandaskan dari Al-Quran, Hadis

\section{${ }^{28}$ Ibid., h. 29-31}

${ }^{29}$ Anisatul Islamiyah Pesan Dakwah dalam Novel Negeri Lima Menara, Jurnal Komunikasi Islam | ISBN 2088-6314 | Volume 05, Nomor 01, Juni 2015 Program Studi Komunikasi dan Penyiaran Islam, Fakultas Dakwah dan Komunikasi Universitas Islam Negeri (UIN) Sunan Ampel Surabaya - Asosiasi Profesi Dakwah Islam Indonesia h 129-136 
dan keputusan ulama. Novel bisa disebut novel Islami karena isi novel tersebut tercantum norma-norma hukum Islam ${ }^{30}$.

Novel Anak Rantau kreasi Ahmad Fuadi memberikan sejumlah kaidah yang tertuang dalam Al-Quran yang diberikan dalam wujud kisah kepada pengagum yang utama ialah tidak boleh untuk mempercayai adanya tuhan selain Allah SWT. Seluruh sesuatu yang ada di muka bumi ialah ciptaan Allah SWT, dan mahluk hidup tidak ada hak untuk tidak mengingat Allah karena seluruhnya akan pulang kepada Sang Penciptanya. Kedua, menyampaikan kepada mahkluk hidup untuk tetap memahai dengan seksama atas laporan atau data yang didapatkannya. Melalui proses terlebih dahulu, namun harus di telaah secara keabsahan laporan atau data didapat.

\section{Pemaparan novel anak rantau kreasi ahmad fuadi.}

1. Riwayat dan Kreasi A Fuadi

Ahmad Fuadi lahir di Bayur, desa kecil yang terletak disisi Danau Maninjau, berdekatan dengan desa tokoh cendekiawan Buya Hamka. Fuadi berkelana ke pulau jawa, menuruti keinginan orang tuanya belajar di pondok pesantren Gontor. Fuadi berjumpa dengan para buya dan pengajar yang memotivasi fuadi dengan setulus hati. Di madrasah ini fuadi berjumpa dengan "miniatur dunia", akibat banyaknya pelajar agama yang berasal dari berbagai tempat, bahkan dari luar negeri. Pengetahuan hidup 4 tahun di Pesantren Gontor ini sebagai gagasan Fuadi membuat novel mega bestseller,Negara5 Menara. Semenjak itu, peribahasa siapa yang bersungguh-sungguh maka ia akan dapat bertambah populer. Tamat pendidikan Hubungan Internasional, UNPAD, Fuadi sebagai seoarang jurnalis Buka Tempo. Di Tahun 1999, Fuadi menerima darma siswa Fulbright untuk melanjutkan studi S2 di sekolah media dan urusan publik, di Universitas George Washington, Amerika Serikat. Cerita berhistori ibarat bencana 11 September diberitakan Faudi dan Dewanti terjun langsung di Pentagon, Gedung Putih dan Bukit Kapur. Di Tahun 2004 Fuadi menerima darma siswa S2 Penghargaan Chevening

${ }^{30}$ Abdurrazaq,Analisis Pesan Dakwah dalam Karya Sastra: Studiatas Publikasi Novel-Novel Islami Karya Habiburrahman El-Shirazy, Jurnal ANTIZAR Vol 19 No 02 Tahun 2013 hal 212 
untuk menimba ilmu di University Royal Holloway of London dalam aspek film dokumenter.

\section{a. Negeri 5 Menara}

Negeri 5 Menara adalah sebuah novel tulisan Ahmad Fuadi yang menjadikan novel pertama dari trilogi dan tiga kreasi novel yakni Negeri 5Menara, Ranah 3 Warna, dan Rantau 1 Muara. Negeri 5 Menara ialah suatu novel yang berkenaan dengan siapa yang bersungguh-sungguh maka ia akan dapat yang maksudnya bagi siapa saja yang melakukan sesuatu dengan niat dan kegigihan yang kuat maka dia akan menuai hasil yang bagus. Novel yang didalamnya mengisahkan tentang jerih payah, optimis, kesungguhan dan kegigihan. Suatu cerita ada enam anak remaja yang ketika petang selalu melihat ke langit dari kaki Tower gubuk Madai yang memimpikan negara impian mereka sendiri-sendiri dari enam anak remaja.

Negeri 5 Menara mengisahkan Angan-angan Alif untuk bisa sekolah di SMA Negeri tetapi keinginan orang tuanya kebalikan dari angan-angan Alif orang tuanya ingin Alif belajar di Pesantren Modern. Dengan berat hati Alif menuruti perkataan ke dua orang tuanya. Ketika pergi ke Pesantren Modern Alif diantarkan ayahnya, setelah Alif menjalani tes dan Alif lulus sehingga Alif menjadi santri atau pelajar di Pesantren Modern. Kemudian seiring bergulirnya waktu, Alif berjumpa dengan lima orang kerabat yang memberikan banyak masukan perihal kehidupan.

b. Ranah 3 Warna

Ranah 3 Warna ialah novel kedua Ahmad Fuadi dari trilogi Negeri 5 Menara. Ranah 3 Warna mengisahkan seorang yang baru saja lulus dari belajar di Pesantren Modern dan meneruskan petuangan Alif untuk mengapai cita-cita menjadi Habibi lalu berkelana menuju Amerika. Keseriusan yang mau diwujudkan oleh Alif bahwa Alif bisa meraih segala impian citacitanya, sekalipun orang lain yang menganggap remeh impian Alif. Persoalan demi persoalan mulai membanjiri. Alif menanggapi persoalan dengan enteng dan kuat hati dan bisa meninggikan akan suatu kaidah yang dipahami ketika di Pesantren Modern ialah siapa yang bersabar akan beruntung 
yang maksudnya bagi orang yang bersabar akan berberhasil. Bernalarkan kedua kaidah yang pertama siapa yang bersungguh-sungguh maka ia akan dapat dan yang kedua siapa yang bersabar akan beruntung Alif melewati persoalan dan pertualangan hidup satu persatu.

c. Rantau 1 Muara

Rantau 1 Muara ialah novel ketiga Ahmad Fuadi dari trilogi Negeri 5 Menara. Rantau 1 Muara mengisahkan yang berhubungan dengan Alif yang telah tamat dari perguruan tinggi dan sukses berdinas di suatu perusahaan yang populer. Alif mulai berdinas dan kian giat berupaya meraih alam impiannya. Amerika sampai memang tiba daratan Amerika menjadi pelajar di Universitas George Washington. Novel Rantau 1 Muara juga mengisahkan betapa Alif berjumpa dengan pasangan hidupnya.

d. Beasiswa 5 Benua

Beasiswa 5 benua adalah jurnal yang dituliskan oleh Ahmad Fuadi yang didalamnya perihal dukungan dan isinya dijelaskan 100 kiat mengejar beasiswa di luar negeri. poin dari artiker Ahmad Fuadi separuhnya berlandaskan pengetahuan hidup Ahmad Fuadi.

e. Anak Rantau

Anak Rantau ialah novel kreasi Ahmad Fuadi yang mengisahkan perjalanan seorang anak yang diberi nama Hepi. Hepi ditinggalkan ayahnya di desa kecil Tanjung Durian dan disekolah desa. Awal mula dari ancaman ayahnya yang mencetuskan jikalau mau pergi ke ibukota, boleh saja dengan syarat memakai uang sendiri. Ancaman yang dicetuskan ayahnya ialah asalnya suatu perpanjalanan kisah hidup yang dilewati oleh Hepi dan kerabat dekatnya Attar dan Zen.

2. Susunan Novel

a. Ringkasan

Bermula dari blangko nilai sekolah kosongpunya Hepi yang diambil Martiaz di sekolah Hepi. Martiaz tak menduga bahwa anakya telah membuatnya kecewa, namun Martiaz mengira bahwa dalam satu tahun ini telah mengajari dan mengusahakan Hepi dengan jerih payah. Bahkan Martiaz memperlihatkan 
penyesalannya, namun martiaz hanya menunjukan wajah yang lesu. Diwaktu itulah timbullah sebuah pemikiran dari kepala Martiaz dengan mengantarkan dan ditinggalkannya Hepi di desa kelahiran di Ranah Minang. Hepi sangat bahagia, sampaisampai anugrah itu datang secara seketika di saat kondisi blangko nilai kosong. Hepi mau menikmati mudik semacam yang di kisahkan teman sejoli Hepi di sekolah, menyangkut serunya petualangan mudik baik dengan kendaraan roda empat atau kapal udara, lalu berjumpa dengan datuk dan opa, dan juga keluarga. Sudah sekitar dua minggu Hepi liburan di desa kelahiran orang tuanya, Tanjung Durian. Martiaz selesai.

\section{E. Analisis komunikasi persuasi dalam novel islami anak rantau}

1. Teknik Gabungan

Ahmad Fuadi dalam novel Islami Anak Rantau tidak sering memakai cara gabungan, berlainan dengan cara-cara persuasi yang lainnya misalnya cara muncul rasa takut, menuntaskan ide, perangkat icing, dan disonansi kognitif. Cara konotasi yang saya dapatkan dalam isi novel Islami Anak rantau pada lembar ke-85. Cara konotasi dalam lembar ke-85 memberikan kaidah satu fenomena yang sedang trending topik secara baik yang bisa dipetik bahwa menjadi mahkluk kita sering himbaukan untuk mempunyai sikap berbaik sangka. Kalau kakek pikir, seharusnya pula Lenon dan komplotan preman ini seperti dia, sedang membayar kekufuran dari kesalahannya di waktu dulu. Dari lubuk hati yang paling dasar, walau sungkan untuk menerima, dia sadar bahwa dirinya lebih buruk daripada yang lain. Namun, apapun itu, penampilannya harus lebih elok. Menggunakan sarung, berpeci,bersorban, bertasbih. lembar 85 .

2. Teknik Muncul Rasa Takut

Penulis mendapatkan 8 carafear arousing dalam novel Islami Anak Rantau. Cara fear arousing dalam novel memberikan laporan yang bisa menimbulkan kegelisahan supaya dengan keinginan individu menjalankan suatu penyelesaian. Laporan supaya bisa tepat waktu dalam menjalankan kebaikan, agar tidak langsung menelan 
informasi yang belum teruji kebenarannya, dan perlunya akan pengajaran sikap terhadap anak.

a. Kalian semua ini masih saudara sepupu. Berkenalanlah dulu. Dan ingat, ketika pas pukul zuhur nanti, ikutlah melaksakan kewajiban bersama datok di masjid. Ingat ya ,ketika beduk bersuara kalian semua harus berada di dalam masjid," ucap dia sembari mengarahkan jari ke masjid disudut jalan. lembar 26.

b. Di pinggir danau, sembari bersila di batu besar, sambil mengecilkan nada, Zen mulai memaparkan. "Itu bangunan keramat. Ditempati penjahat penganut iblis. Dia tidak senang jika seseorang menginjakkan kaki di halamannya. ada dulu seorang yang meraih bola yang ada di halamannya, kemudian perut boah itu mengengbung dan mual-mual seperti disantet. Menurut keyakinan, Cuma disaat hari raya idul adha ilmu santetnya tidak bisa digunakan sementara. Pada waktu itulah bola bisa kita bawa kembali. "ada yang bilang dia dapat melipatkan gandakan uang di dalam gedung itu. tidak usah kerja. Tapi banyak uang," sambung Attar. "Orang hebat. Katanya sih dia bisa mengapung di udara dan berdiri di permukaan air". "Dia keluar tengah malam, mencari kalong untuk disantapnya hidup-hidup, supaya ilmu terbangnya nambah sakti". "siapakah orangnya?" "Julukannya pandeka luko. Dia aib di desa ini, namun belum ada yang mampu menumbangkannya dan menyingkirkannya. Dia memiliki ilmu yang mengerikan yaitu hantaman Tapak Leman beracun, satu hamtaman orang akan mati dengan warna kulit membiru. Ditambah lagi sekarang ini dia sudah kerasukan. Setres. Sebab itu kita jangan mendekatinya." Zen berdongeng perihal pandeka luko saja dia hampir ketakutan.

c. Ayah Hepi pulang sebentar. Dengan tatapan tajam dan mata memerah, Martiaz membentak Hepi, "Pria itu harus bertanggung jawab atas apa yang dilakukannya. Jangan semaumaunya gak masuk sekolah. Semua perbuatan memiliki konsekuensinya. Nimatilah ganjaran atas perbuatan kamu. Jika kamu memang ingin menyusul ayahmu di jakarta, silahkan namun bayar sendiri karcinya jika sanggup." Lembar 54.

d. Dia beranjak berusaha mengetahui jalan mendekatkan diri ke Allah. Di tengah malam dia melaksanakan sholat sunnah, dia mengusap air matanya. Dia merenungkan, bisa saja anak 
kandungnya Martiaz sendiri, sudah menelan rezeki tidak halal dia bawa pulang. Dampaknya, dia sering melawan perintah, ugal-ugalan, dan menjadi seperti saat ini. Lembar 121.

e. Pandangan saya, berkembang atau tidaknya desa kita ini tergantung pada bagaimana cara wali mengajari putra-putrinya. Jika wali mengajari dengan benar, pastilah masyarakat desa akan baik. jikalau walinya acuh tak acuh saja, maka hancurlah anak mereka, rusak juga desa ini. Wali itu seperti tiang negara. Jika walinya tidak perduli, apa yang bisa diwujudkan? Coba tengok, wali teman-teman kamu ini banyak yang lemah, mengabaikan putra-putrinya sungkan dan tak pergi ke masjid. Ada juga yang meminta putranya ke masjid, tapi dianya cuma pergi ke masjid dalam setahun hanya sekali.

Inilah yang dijuluki tungkek bana nanmambao rabah. Yang artinya Tongkat malah yang membawa jatuh rebah, panutanlah yang menimbulkan bencana. Walilah yang mengalah terhadap anak yang salah. Urang awak saat tidak ada sikap. Paham kalian? Lembar 168.

Teknik Gabungan dalam Diskusi ataupun kata Ahmad Fuadi yang memakai cara gabungan dalam novel Anak Rantau sebagai berikut : Kalimat

"Kalau kakek pikir, seharunya pula Lenon dan komplotan preman ini seperti dia, sedang membayar kekufuran dari kesalahannya di waktu dulu.Dari lubuk hati yang paling dasar, walau sungkan untuk menerima, dia sadar bahwa dirinya lebih buruk daripada yang lain. Namun, apapun itu, penampilannya harus lebih elok. Mengunakan sarung, berpeci,beserban, bertasbih". lembar 85 .

Dari diskusi tersebut, bisa ditelaah wujud cara gabungan kepada Lenon yang bahas oleh penduduk Tanjung Durian bahwa Lenon telah bertaubat dan berada di jalan yang lurus. Lenon sering beribadah berjamaah di masjid. Seperti yang sudah disampaikan dalam Al-Quran surat Thaha ayat 82:

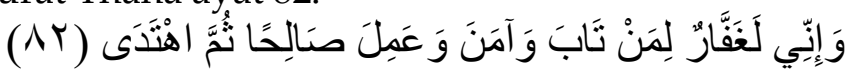

"dan Sesungguhnya aku Maha Pengampun bagi orang yang bertaubat, beriman, beramal saleh, kemudian tetap di jalan yang benar". 
Cara gabungan ini ialah terkait terhadap manusia atau satu fenomena yang sedang populer dibahas secara benar. Jadi disini Lenon menjadi obrolan semua penduduk Tanjung Durian karena Lenon telah melihatkan perilaku baik yang bisa diperoleh penduduk Tanjung Durian. Giat beribadah di masjid, sampai menolong siapapun yang memerlukan pertolongan.

Teknik Membangkitkan Ketakutan Kalimat ;

"Kalian semua ini masih saudara sepupu. Berkenalanlah dulu. Dan ingat, ketika pas pukul zuhur nanti, ikutlah melaksakan kewajiban bersama datok di masjid. Ingat ya ,ketika beduk bersuara kalian semua harus berada di dalam masjid,". ucap dia sembari mengarahkan jari ke masjid disudut jalan. lembar 26.

Dari pembahasan tersebut bisa disimpulkan cara Membangkitkan Ketakutan atau cara yang membangkitkan kegelisahan dan seperti keinginan orang untuk menjalankan satu penyelesaian persoalan. Hepi, Attar dan Zen disuruh oleh embahnya Datuk Marajo untuk selalu dimasjid ketika adzan berbunyi. Dalam cara ini menggambarkan untuk rajin dan giat waktu. Bukan hanya rajin terhadap waktu juga diingatkan dan diharuskan bahwa untuk beribadah diwkatu yang tepat. Seperti yang dipaparkan dalam perintah Allah QS. An-Nisa ayat 103:

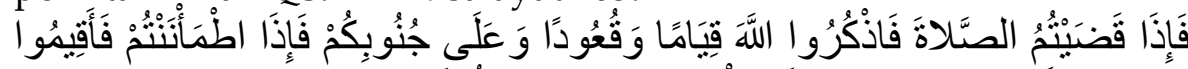

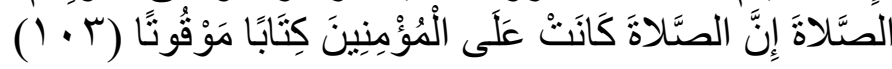

"Maka apabila kamu telah menyelesaikan shalat(mu), ingatlah Allah di waktu berdiri, di waktu duduk dan di waktu berbaring. kemudian apabila kamu telah merasa aman, Maka dirikanlah shalat itu (sebagaimana biasa). Sesungguhnya shalat itu adalah fardhu yang ditentukan waktunya atas orang-orang yang beriman".

Ayat tersebut menyampaikan bahwa Allah SWT telah mentukan dalam Al-Quran bahwa keharusan ibadah sudah ditetapkan pukulnya. Diwajibkan umat Islam untuk dapat melakukan ibadah jika sudah masuk waktunya ibadah. Sholat juga syariatnya fardhu bagi mahluk yang beriman.

\section{F. Simpulan}


Berlandaskan hasil paparan dan kajian pengarang, Ahmad Fuadi menyampaikan dasar-dasar syariat agama Islam yang berasal dari kitab suci Al-Quran dan sunnah Rosulullah SAW menjadi landasan isi kisah pada novel Anak Rantau, supaya bisa menjadi keperluan para pembaca untuk digunakan dalam aktivitas bersosial. Pengkajian pengarang dengan tema teori hubungan persuasi dalam novel Islami Anak Rantau, pengarang memetik titik terang bahwa novel Anak Rantau diambil beberapa kata yang sama seperti teori-teori cara hubungan persuasi yakni, cara gabungan, cara menimbulkan rasa takut, cara membayar gagasan, cara perangkat icing, dan cara kognitif disonansi.

Persuasi ialah teknik atau cara untuk mengubah pola pikir, sifat dan perilaku manusia seperti yang diinginkan penyampai pesan tanpa ada unsur paksaan baik dengan artikel atau perkataan.

a. Cara Gabungan

Cara gabungan ialah cara yang mengaitkan terhadap satu fenomena yang saat ini sedang populer secara baik. Ahmad Fuadi hanya memakai cara gabungan isi pada novel Islami Anak Rantau. Cara gabungan yang dipakai adalah memberikan seruannya dengan menyampaikan suatu kisah yang kajiannya memikat, kelak kisah tersebut akan hangat, dan dibahas secara baik.

b. Cara Menimbulkan Rasa Takut (satu cara untuk memberikan kaidah yang mampu menumbuhkan rasa gelisah)

Ahmad Fuadi memakai cara iniadalah dengan menimbulkan dan mengarang kisah yang menyebabkan rasa gelisah dan mengenai untuk berkeinginan melaksanakan satu penyelesaian.

Cara ini mampu membentuk pembaca berasumsi gerakan apa yang perlu dikerjakan jika terjadi dalam kehidupan nyata.

c. Cara Membayar Gagasan (cara ini diinginkan mampu merubah anggapan dengan impian, bahwa dengan transisi itu bisa menghasilkan hikmah)

Cara ini menggambarkan teknik supaya manusia bisa beralih dengan impian transisi tersebut menuai hikmah. Ahmad Fuadi dalam cara ini, mengarang kisah sesuai dengan keperluan ataupun kenyataan hidup, dengan sendirinya dapat menganti cara berpikir pembaca.

d. Cara Peralatan Icing (cara ini memerlukan harapan, keinginan untuk mempunyai atau menjalankan suatu kegiatan).

Kata-kata yang dibuat oleh Ahmad Fuadi dalam cara ini mampu memicu pembaca kagum. Isi dari kata-kata tersebut sama persis 
dengan ajaran Islam sehingga bisa memicu orang yang membaca menyerap dengan baik dan termotivasi.

e. Cara Kognitif Disonansi (cara ini memetik masalah aktivitas seseorang, dimana sikap tidak sama seperti gagasan dan berlawanan dengan insan) Ahmad Fuadi dalam cara ini memetik sample gejala gejala yang dialami dalam aktivitas seseorang. Sebuah kisah yang dibuat memanfaatkan persoalan yang selalu terjadi dalam diri setiap manusia, yakni satu perilku yang dikerjakan tidak sama seperti kehendaknya. Ahmad Fuadi dalam kisahnya menghimbau bahwa setiap satu persoalan pasti mempunyai titik terang yang bagus, cuma setiap orang maunya jalan pintas.

\section{Referensi}

Amin, samsul Munir. Ilmu Dakwah (Jakarta: Amzah, 2013)

Anas, Ahmad. Paradigma Dakwah Kontemporer (Semarang: PT Pustaka Rizki Putra, 2006)

Aziz, Ali. Ilmu Dakwah Edisi Revisi (Jakarta: Prenadamedia Group, 2016)

Fuadi, Ahmad. Anak Rantau (Jakarta: PT Falco, 2017)

Hanurawan, Fattah. Psikologi Sosial (Bandung: PT Remaja Rosdakarya, 2015)

Hutagalung, Inge. Teori-Teori Komunikasi Dalam Pengaruh Psikologi (Jakarta

Barat: Indeks, 2015)

Ilaihi, Wahyu. Komunikasi Dakwah (Bandung: PT Remaja Rosdakarya, 2010)

Jumantoro, Totok. Psikologi Dakwah (Penerbit Amzah, 2001)

Liliweri, Alo. Komunikasi Serba Ada Serba Makna (Jakarta: Kencana, 2011)

Ma'arif, Bambang Saiful. Psikologi Komunikasi Dakwah (Bandung: Simbiosa Rekatama Media, 2015)

Ma'arif, Bambang Saiful. Psikologi Komunikasi Dakwah (Bandung: Simbiosa Rekatama Media, 2015)

Muhtadi, Asep Saeful. Komunikasi Dakwah (Bandung: Simbiosa Rekatama Media, 2012)

Nurgiyantoro, Burhan. Teori Pengkajian Fiksi (Yogyakarta : Gadjah Mada University Press, 2013)

Nurgiyantoro, Burhan. Teori Pengkajian Fiksi (Yogyakarta : Gadjah Mada

University Press, 2013)

Saerozi. Ilmu Dakwah. 2013 (Yogyakarta: Ombak, 2013)

Sastropoetro, Santoso.Partisipasi, komunikasi, Persuasi dan Disiplin Dalam Pembangunan Nasional (Bandung: Penerbit Alumni, 1998) 
Sukayat, Tata. Ilmu Dakwah (Bandung: Simbiosa Rekatama Media, 2015) Abdurrazaq,Analisis Pesan Dakwah dalam Karya Sastra: Studiatas Publikasi Novel-NovelIslamiKaryaHabiburrahman El-Shirazy, Jurnal ANTIZAR Vol 19 No 02 Tahun 2013 hal 212

Ahmad Zaini, Dakwah Melalui Media CetakAT-TABSYIR, Jurnal Komunikasi Penyiaran Islam Volume 2, Nomor 2, Juli - Desember 2014 68-69

Anisatul Islamiyah Pesan Dakwah dalam Novel Negeri Lima Menara,Jurnal Komunikasi Islam | ISBN 2088-6314 | Volume 05, Nomor 01, Juni 2015 Program Studi Komunikasi dan Penyiaran Islam, Fakultas Dakwah dan Komunikasi Universitas Islam Negeri (UIN) Sunan Ampel Surabaya - Asosiasi Profesi Dakwah Islam Indonesia h 129136

Anton Widodo, Fathurohman, Dakwah Islam Di Era Revolusi Industri 4.0,

Khabar: Jurnal Kounikasi Penyairan Islam, Vol.1 No.1 Juli-Desember 2019

Harles Anwar\& MualiminDAKWAH MELALUI PEMBINAAN KEAGAMAAN TERHADAP MASYARAKAT MUSLIM PEDALAMAN OLEH PENYULUH AGAMA ISLAM NON PNS KECAMATAN TEBAS, SAMBAS, Jurnal Bimbingan penyluhan Islam Vol.1 No.1 januari-Juni 2019

Mubasyaroh, Strategi Dakwah Persuasif dalam Mengubah Perilaku Masyarakat, Ilmu Dakwah: Academic Journal for Homiletic Studies Volume 11 Nomor 2 (2017) 311-324DOI: 10.15575/idajhs.v12i.2398http://journal.uinsgd.ac.id/index.php/idajhs ISSN 1693-0843 (Print) ISSN 2548-8708 (Online) hal 313-315 